\title{
Pembelajaran Karawitan Liturgi Pada Kelompok Karawitan Remaja Gita Rarya Di Yogyakarta
}

\author{
Agustina Ratri Probosini', Albertus Wisnu Aji Nugroho ${ }^{2}$ \\ 1,2Jurusan Sendratasik, Fakultas Seni Pertunjukan Institut Seni Indonesia Yogyakarta
}

\begin{abstract}
One of the weekly Eucharist Celebrations (Mass) in Gereja Hati Kudus Tuhan Yesus (GHKTY) Pugeran is held using the instrument of gamelan as form enculturation church music. The existence of Gita Rarya as group of karawitan, established by FX. Wiyono, who is responsible for the mass instrument is one of the froms of the process lessons. Therefore, the aim of the research is to describe the liturgical karawitan in GHKTY Pugeran applied by karawitan teens group Gita Rarya and describe the learning process of liturgical karawitan on karawitan teens group Gita Rarya. This research is a qualitative research with didactic approach. To get written data, research library method is used. Meanwhile, the methods of observation, interview, and recording used for obtain oral data. The technique of sample taking from the available population is the technique of purposive sampling. This particular technique is used to aim the advanced depth of the study. The conclusion that can be delivered is that for over 10 years, the karawitan teenagers group Gita Rarya consistently take part in the implementation of Catholic liturgy and the progress in mastering the church instrument is used, especially the tabuhanimbal technique. Gita Rarya have high taste in musicality and their existences as pengrawit in GHKTY Pugeran is strengthen because they perform their duties with pleasure.
\end{abstract}

Keywords: learning; liturgical karawitan; teenagers.

\begin{abstract}
Abstrak
Lagu model merupakan lagu yang digunakan sebagai media dalam mencapai pembelajaran berdasarkan tema. Yang menjadi kendala dalam proses penciptaan lagu adalah perbedaan kemampuan musikal mahasiswa antara latar belakang pendidikan musik dan mahasiswa di Prodi PG-PAUD. Penelitian ini bertujuan untuk mendeskripsikan optimalisasi proses pembelajaran cipta lagu untuk pembelajaran anak usia dini. Penelitian ini menggunakan pendekatan kualitatif. Subjek dalam penelitian ini adalah mahasiswa tingkat II di kelas A, B, C, dan D yang berjumlah 59 orang mahasiswa. Penelitian ini dilaksanakan pada semester genap tahun akademik 2015/2016, dengan teknik pengumpulan data berupa wawancara, observasi, dan studi dokumentasi. Hasil penelitian menyimpulkan bahwa cara untuk mengoptimalkan penciptaan "Lagu Model" anak usia dini adalah melalui pembuatan sinopsis, pelaksanaan metode diskusi kolaboratif, apresiasi, serta pendokumentasian lagu dalam bentuk CD dan Buku. Dengan adanya metode yang tepat dalam mengoptimalkan proses pembelajaran, maka dapat meningkatkan kualitas lagu yang diciptakan oleh mahasiswa.
\end{abstract}

Kata kunci: Optimalisasi; Lagu Model; Anak Usia Dini

\section{Pengantar}

Musik merupakan pendukung utama dalam peribadatan gereja. Musik diatonik lebih banyak dipergunakan daripada pentatonik. Meskipun demikian tidak sedikit gereja menggunakan gamelan sebagai bagian yang tidak terpisahkan dari serangkaian peribadatan. Di Jawa peribadatan gereja
Katolik juga ada yang menggunakan iringan gamelan (Jawa). Pada tahun 1958 Gereja Hati Kudus TuhanYesus (GHKTY) Pugeran menjadi Gereja Katolik pertama yang memasukkan gamelan secara resmi sebagai kelengkapan ibadat (Tim Redaksi Buku Kenangan "Peduli, Berbagi, Gembira", 2014: 48). Baru pada tahun 1962-1965 ada 
tanggapan dan penegasan dari Konsili Vatikan II tentang sikap Gereja Katolik yang terbuka terhadap kebudayaan setempat (Y. Sumandiyo Hadi, 2000: 39). Salah satu Gereja Katolik yang menggunakan gamelan adalah Gereja Hati Kudus Tuhan Yesus Pugeran Yogyakarta. Gamelan kebanyakan digunakan pada perayaan ekaristi mingguan di gereja, tetapi tidak menutup kemungkinan untuk mengiringi ibadat lain seperti ibadat tata laksana mengantar jenazah ke pemakaman.

Perayaan ekaristi mingguan di GHKTY Pugeran diadakan 6 kali, 5 diiringi organ dan sekali menggunakan gamelan. Kesiapan petugas kor, pengiring kor (organis dan pengrawit) harus solid untuk mendukung kekhusukan tata laksana peribadatan. Tata laksana perayaan ekaristi yang terdiri dari beberapa bagian memerlukan 10-15 lagu baik berupa lagu umat, solis, atau lagu dialogis antara pemimpin ibadat dan umat. Sekarang, ada 7 kelompok pengrawit yang menjadi petugas tetap perayaan ekaristi gending, salah satunya Gita Rarya.

Gita Rarya merupakan kelompok pengrawit remaja binaan F.X. Wiyono sejak tahun 2004. Keberadaannya cukup membanggakan karena merupakan satu dari sedikit kelompok karawitan anak-remaja yang dapat bertahan sebagai pengiring perayaan ekaristi di GHKY Pugeran. Pada mulanya para anggotanya belajar karawitan liturgi bermodal niat. Meskipun hanya berlatih satu minggu sekali dan penambahan frekuensi latihan jika liburan sekolah, Gita Rarya mampu mengiringi perayaan ekaristi sekitar 3 bulan setelah terbentuknya kelompok. Sejak saat itu Gita Rarya bertugas paling tidak 7 minggu sekali dan menyajikan gending-gending yang disesuaikan dengan tahun liturgi yang sudah pakem ditentukan oleh Gereja Katolik. Gending-gending yang ada dalam karawitan liturgi Katolik tidak sepenuhnya sama dengan karawitan pada umumnya, terutama dalam hal strukturnya yang lebih sederhana. Keberadaan Gita
Rarya sebagai kelompok pengrawit remaja yang eksis di GHKTY Pugeran tidak lepas dari proses pembelajaran yang dilakukan. Dari permasalahan di atas, penulis mengajukan pertanyaan (a) Bagaimana karawitan liturgi di GHKTY Pugeran yang diterapkan oleh kelompok karawitan remaja Gita Rarya dan (b) Bagaimana proses pembelajaran karawitan liturgi pada kelompok karawitan remaja Gita Rarya?

Penelitian ini berbeda dengan tulisan-tulisan yang pernah ditulis oleh penulis sebelumnya. Y. Sumandiyo Hadi dalam bukunya Seni dalam Ritual Agama (2000) memaparkan latar belakang, tujuan, macam dan proses inkulturasi musik gereja. Macam inkulturasi di antaranya (1) inkulturasi liturgi, (2) inkulturasi hidup rohani, dan inkulturasi teologi. Sebagai sampel utama adalah Gereja Hati Kudus Tuhan Yesus Ganjuran. Penelitian ini mengembangkan salah satu macam inkulturasi yaitu inkulturasi liturgi di bidang musik

Dalam bukunya yang berjudul Inkulturasi Gamelan Jawa, Studi Kasus di Gereja Katolik Yogyakarta Sukatmi Susantina mengungkapkan pentingnya suatu proses inkulturasi. Sebagai suatu proses, inkulturasi tidak pernah mandeg sejalan dengan kebudayaan yang selalu berkembang. Selain itu juga merupakan perwujudan Gereja Katolik dalam usaha mewartakan Injil dan nilai-nilai kehidupan melalui bentuk yang sesuai dengan kebudayaan setempat. Nilainilai dalam seni karawitan liturgi patut untuk ditanamkan sedini mungkin sehingga proses regenerasi berjalan seperti yang diinginkan. Hal ini diterapkan pada keterlibatan Gita Rarya dalam menanggapi inkulturasi Gereja Katolik.

Buku karangan Subuh yang berjudul Gamelan Jawa Inkulturasi Musik Gereja: Studi Kasus Gending-Gending Karya C. Hardjasoebroto (2006) memaparkan sosok seniman dan ilmuan serta analisis gendinggending ciptaan C. Hardjasoebroto. Hasil analisisnya antara lain adanya perpaduan 
bentuk gending juga perpaduan konsep matra/birama dengan konsep gatra dalam karawitan. Gending-gending karya C. Hardjasoebroto banyak digunakan dalam Liturgi Gereja Katolik. Konsep perpaduan di atas terdapat pada materi gending-gending yang dijarkan pada Gita Rarya

Konsep belajar Ki Hajar Dewantara, yaitu Tringo: Ngerti, Ngrasa, Nglakoni (Sumardi, 2012) dimungkinkan untuk dipakai dalam proses pembelajaran karawitan liturgi GHKTY Pugeran. Ngerti adalah berkaitan dengan aspek kognitif atau meliputi proses rasional untuk menguasai pengetahuan dan pemahaman kontekstual dengan pengetahuan yang kita dapat dari pendidikan formal maupun nonformal. Unsur-unsurnya dari tingkat terbawah adalah pengetahuan, pemahaman, penerapan, analisis, sintesa, dan evaluasi.

Ngrasa sangat berhubungan erat dengan afektif yaitu berkaitan dengan sikap, perasaan, dan nilai seseorang sebagai pribadi dan juga sebagai makhluk sosial. Nglakoni adalah aspek psikomotor bagaimana seseorang melakukan aktifitas, kegiatan atau praktik untuk membuktikan lebih memperdalam teori yang telah dipelajari, dalam hal ini adalah kemampuan memainkan gamelan.

Menurut Ki Hadjar Dewantara (2013: 28) ada 6 cara mendidik: (1) Memberi contoh (yang sesuai diterapkan anak usia 1-7 tahun), (2) Pembiasaan (yang sesuai diterapkan anak usia 1-7 tahun), (3) Pengajaran (yang sesuai diterapkan anak usia 7-14 tahun), Perintah, Paksaan, dan Hukuman (yang sesuai diterapkan anak usia 7-14 tahun), (5) Laku, (yang sesuai diterapkan anak usia 1421tahun),(6) Pengalaman Lahir dan batin (yang sesuai diterapkan anak usia 14-21 tahun).

Penelitian ini berjenis kualitatif dengan pendekatan didaktik. Hal ini berarti penelitian ini bertujuan untuk mengungkap objek dalam bentuk deskriptif yang disertai dengan analisis terhadap pembelajaran karawitan liturgi. Untuk mendapatkan data tertulis digunakan metode penelitian pustaka, sedang metode observasi, wawancara, dan rekaman digunakan untuk memperoleh data lisan. Teknik pengambilan sampel dari populasi yang ada adalah teknik purposive sampling dengan tujuan untuk mengungkap kedalaman kajian.

\section{Pembahasan}

1. Karawitan Liturgi di Gereja Hati Kudus Tuhan Yesus Pugeran

Liturgi adalah perayaan iman Gereja akan misteri penyelamatan Allah, yang terlaksana melalui Yesus Kristus dalam persekutuan dengan Roh Kudus (Sumandyo Hadi, 2000: 184). Gereja Hati Kudus Tuhan Yesus Pugeran merupakan lembaga peribadatan dengan yang memiliki umat 12.250 orang ("Berbagai Catatan Paroki Pugeran Tahun 2016", 2016: 4), berlokasi di Jalan Suryaden/Bantul 63 Yogyakarta. Pastur kepala paroki adalah Paulus Supriyo, sedang pastur lain yang bertugas di Paroki Pugeran adalah F.X. Wiyono, J. Sari Jatmiko, dan Winaryanto. Tugas utama para pastur (biasa disebut juga romo) memimpin Misa Kudus (misa) dengan bahasa Indonesia dan Jawa. Adapun lagu Iringan Misa Kudus. Satu rangkaian gending untuk misa berbahasa Jawa terdiri dari 12 gending, yaitu

1. Kidung Pambuka

2. Gusti Nyuwun Kawelasan

3. Minulya

4. Mazmur Tanggapan

5. Allelua

6. Rinesepna

7. Cecawis Pisungsung

8. Suci

9. Anamnese

10. Ayem Tentrem (tentatif)

11. Komuni

12. Panutup 
Lagu-lagu diambil dari buku Kidung Adi, sebuah buku wajib bagi umat Katolik yang berisi doa dan nyanyian berbahasa Jawa, Madah Bakti dan Puji Syukur yang berbahasa Indonesia serta buku Mazmur Tanggapan Dan Alleluia. Namun tidak menutup kemungkinan lagu-lagu diambil dari buku-buku lagu liturgi, seperti Bernyanyilah Bagi Tuhan, Berkatilah Kami Tuhan, Ayo Puji Tuhan.

\section{Profil Gita Rarya}

Pada mulanya Gita Rarya adalah nama kelompok kor anak yang didirikan pada 29 September 2004. Anak-anak yang menjadi anggota kelompok kor tersebuat merupakan peserta lomba nyanyi tunggal di GHKTY Pugeran. Nama Gita Rarya diberikan oleh G. Suprayitno, pastur paroki pada waktu itu. Arti namanya anak yang bersuka ria (Wawancara dengan F.X. Wiyono,1 Juni 2017) suara surgawi (Wawancara dengan Daisy, 23 Juni 2017), nyayian anak (Wawancara dengan Atik, 9 Juli 2017). Latihan karawitan pertama dihadiri 15 anak. Selanjutnya, keterampilan menabuh Gita Rarya bertambah baik. Materi gending yang dipelajari juga bertambah. Dengan dukungan orang tua khususnya ibuibu dari anggota Gita Rarya, kegiatan tugas gereja bertambah dengan mengiringi misa dengan berbagai ujud (permohonan) dilaksanakan baik di dalam atau luar gereja. Selanjutnya, Gita Rarya diajak lagi oleh lingkungan Mangkuyudan yang mempunyai kelompok kor bahasa Jawa untuk bertugas rutin mengiringi misa hari Minggu setiap 7 minggu. Gita Rarya juga belajar memainkan gending non-liturgi seperti Sampak, Srepegan, dan Playon untuk mengiringi pentas wayang wahyu paket padat (2-3 jam). Bahkan, event lomba juga diikuti.

\section{Proses Pembelajaran Karawitan Liturgi} pada Kelompok Ramaja Gita Rarya

Bermula dari pengamatan pada saat tugas kor di Serangan, F.X. Wiyono mempunyai pikiran bahwa anak-anak Gita Rarya berbakat musik. Di sisi lain, hamper semua belum mengenal gamelan. Oleh karena itu, Wiyono menerapkan metode belajar dengan dasar "rasa senang" (Wawancara dengan Daisy, 23 Juni 2017 dan Atik, 9 Juli 2017) sebagai berikut.

a. Metode Pembelajaran

1) Belajar $\neg$ mathet

Mathet adalah menghentikan gema bunyi pada beberapa intrumen gamelan khususnya wilahan logam. Dalam proses pembelajaran karawitan bagi pemula istilah mathet dilakukan pada instrumen balungan dan slenthem dengan tangan kiri. Caranya dengan menekan bilah instrumen dengan ibu jari dan telunjuk. Posisi bilah ada di antara ibu jari dan telunjuk, ibu jari di atas bilah dan telunjuk di bawah bilah yang sama. Lama melakukannya disesuaikan dengan perpindahan nada atau bilah yang ditabuh. Selain balungan dan slethem, instrumen yang digunakan untuk belajar mathet adalah gender. Semua anak yang hadir bebas memilih instrumen yang ditabuh dan sesuai yang diinginkan. Tahap ini dilakukan pada akhir pertemuan pertama dan kedua.

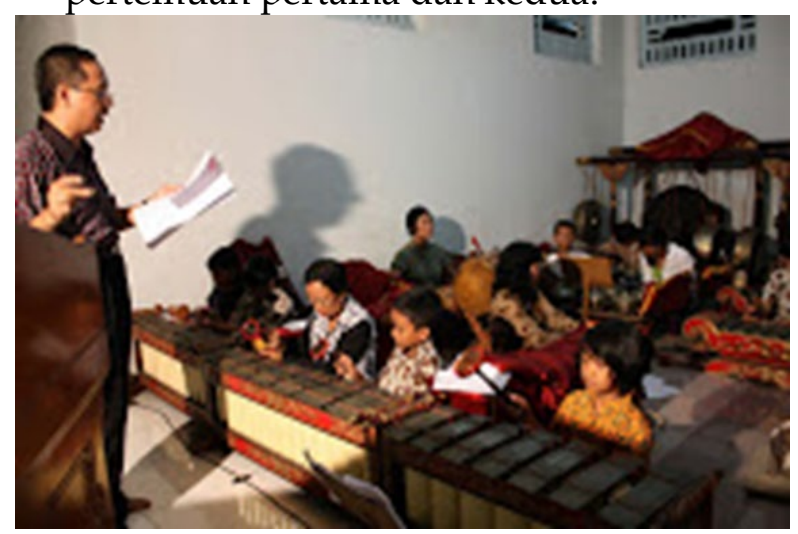

Gambar 1 Anggota Gita Rarya pada awal latihan sedang berlatih mathet dan mengenal nada. (Foto: Koleksi Gita Rarya)

2) Mengenal nada

Secara acak semua anak yang hadir diposisikan duduk di dekat beberapa instrumen untuk belajar menabuh. Instrumen tersebut gender barung, 
gender penerus, slenthem, demung, saron, peking, bonang barung, bonang penerus, kenong, kempul, dan gambang. Anak-anak memegang satu tabuh, lalu diajak untuk memukul beberapa nada dengan tempo yang diatur oleh Wiyono. Nada yang dikenalkan pelog karena karawitan liturgi di GHKY Pugeran sebagian besar menggunakan galeman pelog. Notasi tidak ditulis tetapi diucapkan oleh Wiyono dan dibarengi dengan gerak ibu jarinya. Nada 1 dengan telunjuk; 2 dengan telunjuk dan jari tengah; 3 dengan telunjuk, jari tengah, dan jari manis; 4 dengan telunjuk, jari tengah, jari manis, dan kelingking; 5 dengan ibu jari, telunjuk, jari tengah, dan jari manis; 5 dengan ibu jari, 7 dengan ibu jari dan telunjuk. Anak-anak diperintahkan untuk memukul sekeras mungkin instrumen yang dipegang dengan maksud supaya nada atau ngeng cepat ditangkap anakanak. "Gamelane ditabuh sak sero-serone, mengko nek jebol tuku meneh" begitu kata F.X. Wiyono berujar supaya anakanak tidak ragu-ragu memukul gamelan (Wawancara dengan Atik, 9 Juli 2017). Beberapa rangkaian nadanya sebagai berikut: (a) 61615151 dan (b) 1315 1315 . Hal ini dilakukan sampai semua anak mengenal semua nada. Selanjutnya pengenalan nada ditambah, dengan not (c) 61615151, (d) 21656521 , (e) 3 2656521 , (f) ..21 $2356 \quad \ldots 212$ 365 , dan (g) 327676 32. Tahap ini dilakukan pada pertemuan ketiga.

3) Membaca notasi

Notasi langsung ditulis di teks dan dibagi sejumlah anggota yang hadir. Penulisan notasi lebih sederhana daripada penulisan notasi karawitan pada umumnya. Meskipun demikian, tanda-tanda utama tetap ada. Selain not angka juga terdapat tanda-tanda untuk (1) buka, (2) umpak (jika ada), (3) penggolongan ulihan (A, $\mathrm{B}$,$) , (4) penggolongan irama (I, II), (5)$ gong, (6) kenong, (7) kempul. Pada tahap ini, selain balungan dan slenthem, anakanak sudah diperkenalkan dengan bonang barung, bonang penerus, kenong, kempul, dan gong. Pada tahap ini F.X. Wiyono sudah dapat menentukan casting penabuh dan instrumennya. Pada tahun pertama, kendang ditabuh oleh Suatmaji , umat yang dipercaya sebagai salah satu asisten mengajar. F.X. Wiyono menerangkan teknik menabuh instrument-instrumen tersebut. Dengan notasi sederhana, dipraktikkan berulangulang, akhirnya anak-anak mulai terampil.

4) Memainkan bentuk gending ketawang dan lancaran

Bentuk gending yang pertama diperkenalkan adalah Lancaran Bindri dan Mayar Sewu. Instrumen yang ditabuh slenthem, demung, saron, peking, bonang barung, bonang penerus, kenong, kempul, dan gong. Tahap ini dilaksanakan dalam sekali pertemuan.

5) Memainkan gending liturgi

Gending liturgi yang pertama dikenalkan adalah Rawuha Roh Kang Suci. Lagu ini dipilih oleh Wiyono karena sederhana dan cocok bagi pemula. Rawuha Roh Kang Suci ciptaan JB Sukodi ditulis di buku Kidung Adi nomer 378. Termasuk bentuk lancaran, laras pelog pathet I 5, wirama I, buka celuk gong 1 , terdiri dari 6 gatra not. Setelah mempelajari gending tersebut, anak-anak Gita Rarya semakin bersemangat mempelajari gending liturgi, terutama ordinarium. Kemudian empat gending yang termasuk ordinarium dipelajari untuk persiapan tugas perdana.

b. Hasil belajar

Ada beberapa hasil belajar sejak latihan pertama sampai saat ini, yaitu:

1. Anggota Gita Rarya menguasai gending-gending liturgi baik yang ada di Kidung Adi jilid I, II, III, Kidungan Jemuah Adi, dan Kidung Puji Agung 
serta Ordinarium karangan F.X.Wiyono dan Y.B. Sukodi yang belum dibukukan.

2. Anggota Gita Rarya menguasai gending-gending pengiring wayang wahyu, di antaranya sampak, srepegan, dan playon

3. Anggota Gita Rarya menguasai gending-gending lainnya, terutama materi lomba

4. Tiap anggota mampu menabuh instrumen yang sejak awal dipelajari, namun juga dapat memainkan instrumen lain, kecuali ricikan ngajeng

5. Kebersamaan antaranggota semakin kompak, baik dalam menabuh gamelan maupun pergaulan.

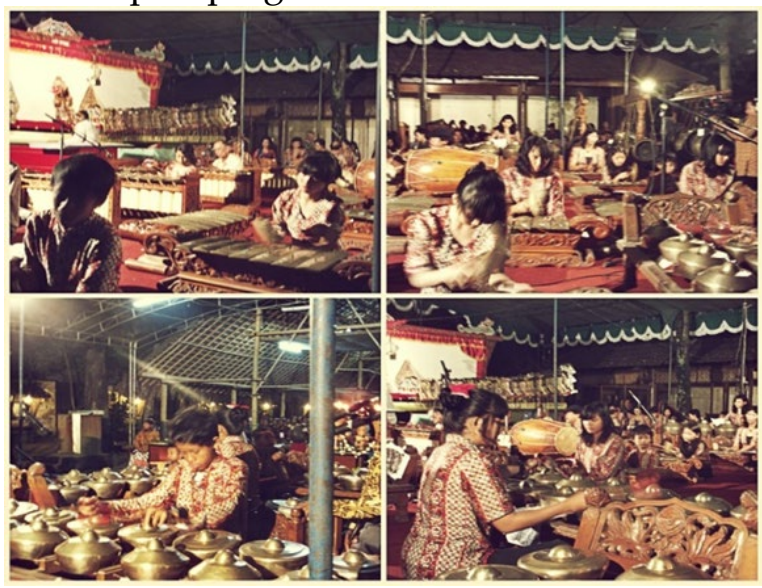

Gambar 2 Gita Rarya mengiringi Wayang Wahyu dengan dalang F.X. Wiyono (Foto: Koleksi Girta Rarya)

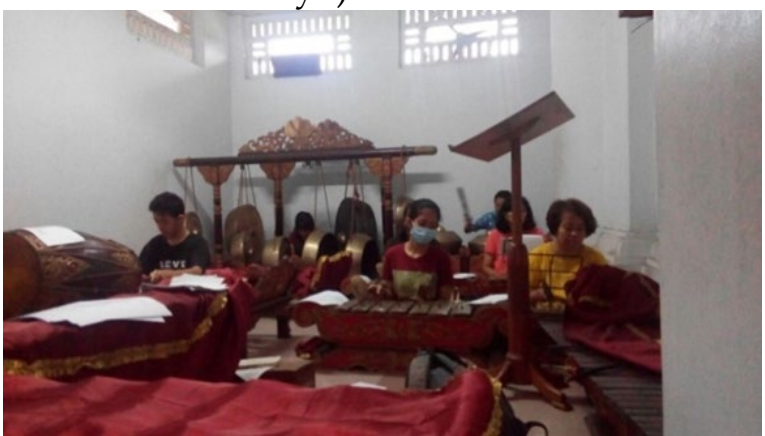

Gambar 3 Gita Rarya sedang latihan untuk persiapan tugas (Foto: Koleksi A. R. Probosini, 2017)

\section{Karawitan liturgi di GHKTY Pugeran yang diterapkan oleh kelompok karawitan remaja Gita Rarya}

Karawitan liturgi di sini akan difokuskan pada gending gereja yang dimainkan Gita Rarya untuk mengiringi kor. Hal ini dikaitkan dengan fungsi utama kelompok karawitan gereja Katolik adalah memainkan gending-gending gereja untuk mengiringi kor dalam menyanyikan lagu-lagu liturgi. Lagu atau nyanyian merupakan bagian penting dari liturgi Gereja Katolik. Peran nyanyian yang begitu penting, bahkan menyatu dengan liturgi itu sendiri, kelompok kor (dan pengiringnya) juga berperan penting dalam liturgi (Agus Tridiatno, 2010: 3). Adapun aspek-aspeknya pembelajaran karawitan pada Gita Rarya.

a. Aspek Musikal

1) Notasi vokal lagu-lagu gereja semua menggunakan notasi Solmisasi, sedangkan notasi gamelan menggunakan notasi Kepatihan. Ini berarti kelompok kor menggunakan notasi nada diatonis/Solmisasi dan pengrawit menggunakan notasi nada pentatonis/Kepatihan. Hal ini menimbulkan permasalahan pada penyesuaian warna suara dan kelompok kor di GHKTY Pugeran warna diatonisnya masih sangat dominan (Subuh, 2006: 113-114), termasuk kelompok kor lingkungan Mangkuyudan yang selama 9 tahunan diiringi Gita Rarya.

2) Berdasar matra/birama musik diatonis, jatuhnya tekanan setelah garis birama, sedangkan dalam penulisan balungan yang menggunakan gatra jatuhnya tekanan pada hitungan ke empat (Subuh, 2006: 119). Hal ini dipahami oleh semua anggota Gita Rarya sehingga jika ada kesalahan dimulainya nyanyian, semua akan tau dan usul pada kelompok kor untuk mengulanginya tentunya bersama dengan iringan gamelan (Wawancara dengan Atik, 9 Juli 2017)

3) Penggolongan bentuk gending gereja di Yogyakarta yakni Lancaran, Ladrangan, Ketawangan, Gangsaran, dan Bubaran yang termasuk gendhing alit terbukti dapat digunakan bersamaan dalam satu gending, Contohnya lagu Tantum Ergo I yakni 
menggunakan bentuk ladrang dengan ketawang (Subuh, 2006: 127-129). Maskipun demikian, ada beberapa gending yang tidak termasuk gendhing alit, tengahan, atau gedhe yang pernah dimainkan Gita Rarya, seperti Alleluyah (KA 107, 108), Rinesepna (KA 110 A), Sembahyangan Umat (KA 115), Anamnese III dan IV (KA 127-128). Untuk melakukan tabuhan yang baik dalam rangkaian gatra singkat, dibutuhkan konsentrasi yang baik. Gita Rarya dapat melakukannya dengan baik karena gendinggending tersebut sering bahkan wajib dimainkan dalam misa.

4) Sementara itu, ada beberapa lagu gereja yang bermatra $3 / 4$ seperti Pangon Utama, juga perpaduan 4/4 dengan 6/8 pada lagu Bojana Agung). Lagu Bojana Agung sering disajikan Gita Rarya dalam Misa Kamis Putih. Dengan latihan yang baik dan sajian berulang-ulang, Gita Rarya dapat melakukannya dengan baik, khususnya pada perpindahan matra.

5) Dalam penyajian gending gereja terjadi akulturasi dalam aspek orkestrasi, yaitu terjadinya paduan antara tugas kendang dengan dirigen. Kendang mengendalikan karawitan instrumennya, sedang dirigen mengendalikan kor (vokalnya). Keduanya harus dapat bekerja sama untuk menyajikan gending gereja dengan baik (Subuh, 2006: 140). Untuk itu, dirigen berdiri di depan kelompok kor tetapi harus terlihat juga oleh pengendang. Hal lain yang dilakukan Gita Rarya yakni dengan mengadakan latihan secukupnya dengan kelompok kor terutama dirigen. Meskipun "jam terbangnya" sudah cukup tinggi, Gita Rarya sampai sekarang mengharuskan latihan bersama tersebut, meskipun hanya sekali (Wawancara dengan Daisy, 23 Juni 2017)

6) Ada beberapa pengelompokan ricikan (Martopangrawit, 1975):

1.Fisik/bentuk: wilahan dan pencon,

2. Unsur musikal: balungan (demung, saron, peking, slenthem, bonang panembung), pamurba irama (kendang), pamurba lagu (rebab, bonang, gendèr, sinden), pamangku irama (kethuk, kenong, kempul, gong), pamangku lagu (gendèr, bonang barung, gambang), penghias lagu (gambang, siter, suling, bonang penerus, bonang barung)

3. Prespektif garap: balungan, struktural (kethuk, kenong, kempul, gong), garap (rebab, kendang, gender, sinden)

4. Hirarki/possi kedudukan: ngajeng (rebab, kendang, gender, sinden), tengah (bonang barung, balungan, ricikan struktural), wingking (siter, gambang, suling, bonang penerus, gender penerus,kecer, kemanak, keplok alok)

Meskipun ada casting tetap untuk ricikan tertentu jika sekali waktu penabuh (tetap) tidak dapat tugas karena alasan tertentu, anggota yang lain siap menggantikannya.

Anggota Gita Rarya dapat memainkan:

1. Ricikan wilahan dan pencon

2. Ricikan balungan (demung, saron, peking, slenthem, ricikan pamurba irama (kendang), pamurba lagu (bonang), ricikan pamangku irama (kethuk, kenong, kempul, gong), pamangku lagu (bonang barung), penghias lagu (bonang penerus, bonang barung)

3. Ricikan struktural (kethuk, kenong, kempul, gong), garap (kendang)

4. Ricikan ngajeng (kendang), tengah (bonang barung, balungan, ricikan struktural (kethuk, kenong, kempul, gong), wingking (bonang penerus)

5. Keterampilan menabuh gamelan antara anggota Gita Rarya putra dan putri tidak ada perbedaan yang signifikan. Hanya untuk pengendang selama ini dimainkan oleh putra. Selama Gita Rarya belajar menabuh gamelan, bertugas mengiringi kor gending, ikut lomba, dan melakukan berbagai kegiatan di bidang karawitan, anggota Gita Rarya belum ada yang belajar ricikan pamurba lagu (rebab, gendèr), pamangku lagu (gendèr), penghias irama (kemanak, kecer, keprak, kemong, keplok), penghias lagu (gambang, siter, suling) karena pada awalnya anggotanya masih berusia anak 
Sekolah Dasar. Jadi ricikan yang diajarkan adalah berkategori mudah yakni menabuh notasi pokok dengan balungan. Di samping itu secara musikal dirasa cukup untuk sebuah sajian pemula dengan pamurba irama (kendang), pamurba lagu (rebab, bonang barung saja), pamangku irama (kethuk, kenong, kempul, gong), pamangku lagu (bonang barung saja), dan penghias lagu (bonang penerus dan bonang barung). Aspek penghias irama dirasa tidak begitu pokok untuk sebuah sajian pengrawit pemula maka tidak diajarkan penghias irama. Di samping itu, sejak awal jika bertugas mengiringi kor Gita Rarya dibantu oleh bapak atau ibu yang kompeten di bidangnya dalam menabuh rebab, gendèr sebagai pamurba lagu dan pamangku lagu, serta gambang, siter, suling sebagai penghias lagu.

b. Aspek Nonmusikal

1) Menurut Subuh (2009: 141) terjadi akulturasi pada posisi duduk pengrawit dan vokalis di gereja, khususnya GHKY Pugeran. Pengrawit duduk bersil (lesehan) sedang kelompok kor duduk di bangku. Gita Rarya duduk lesehan beralaskan karpet di panti gamelan, tepat di sisi selatan panti imam. Kelompok kor duduk di bangku di sisi barat panti gamelan, terpisah oleh tembok berornamen ukiran kayu. Sementara itu, karena sejak awal latihan sudah dibiasakan dengan notasi dalam bentuk teks (Wawancara dengan Atik, 9 Juli 2017), maka diupayakan pembuatan standar partitur yang ukurannya disesuaikan dengan posisi duduk.

2) Dalam tugas rutin di gereja atau misa di luar gereja Gita Rarya berkostum bebas rapi dan bertata rias natural. Kostum khusus akan digunakan untuk event- event khusus, seperti lomba atau misa khusus, di antaranya Misa Sakramen Penguatan/Krisma, HUT Gereja dan sebagainya.

\section{Pembelajaran karawitan liturgi pada kelompok karawitan remaja Gita Rarya}

Metode pembelajaran yang konvensional dilakukan pada pemula yakni dengan tahap pengenalan etika; nama, bentuk, dan fungsi instrumen; baru kemudian cara menabuh sekaligus pengenalan laras, bentuk gending, dan praktek berurutan dari ricikan balungan, pamangku irama (kethuk, kenong, kempul, gong), pamangku lagu (bonang barung), penghias lagu (bonang penerus) (Wawancara dengan Antonia Indrawati 22 November 2017).

Berbeda dengan metode yang diajarkan kepada Gita Rarya bahwa pengenalan etika tidak serta merta diberikan pada awal pembelajaran. Hal ini dikatakan oleh F.X. Wiyono bahwa anak-anak diberi kepercayaan untuk menabuh dulu dengan posisi duduk yang bebas dan belum perlu diberi pengertian tentang perlakuan terhadap gamelan (misalnya tidak boleh melompati ricikan $\mathrm{dsb}$ ) supaya menumbuhkan rasa senang menabuh lebih dahulu (Wawancara dengan F.X. Wiyono, 1 Juni 2017). Hal itu ditegaskan oleh Daisy bahwa jika anak-anak dikenalkan dengan etika lebih dahulu kemungkinan akan menganggap bahwa menabuh gamelan itu banyak aturan dan membosankan (Wawancara dengan Daisy, 23 Juni 2017). Dengan demikian dapat dikatakan bahwa pengenalan etika dan nama, bentuk, fisik, fungsi instrumen dilakukan dengan terintegrasi pada saat praktek. Pada tahap praktik pada Gita Rarya hampir sama dengan pembelajaran yang diajarkan Indrawati yakni belajar mathet, mengenal nada termasuk laras, bentuk gending dan Gita Rarya ditambah dengan pengenalan gending liturgi.

Sementara itu menurut Sumardi (2012), proses pembelajaran pertama adalah ngerti. Ngerti berkaitan dengan aspek kognitif atau meliputi proses rasional untuk menguasai pengetahuan dan pemahaman kontekstual dengan pengetahuan yang kita dapat dari pendidikan formal maupun nonformal. Unsur-unsurnya dari tingkat terbawah 
adalah pengetahuan, pemahaman, penerapan, analisis, sintesa, dan evaluasi. Anggota Gita Rarya melalui tahap-tahap tersebut. Pengetahuan diberikan melalui metode ceramah dan demontrasi yang disampaikan F.X. Wiyono. Pemahaman diwujudkan dalam pengulangan praktik menabuh, Penerapan dilakukan dengan langsung dipraktikkannya teori yang baru saja diterangkan. Analisis, sintesa dan evaluasi dilaksanakan pada saat latihan serta tugas/pentas dan setelahnya.

Ngrasa sangat berhubungan erat dengan afektif yaitu berkaitan dengan sikap, perasaan, dan nilai seseorang sebagai pribadi dan juga sebagai makhluk sosial. Menurut Daisy (Wawancara 23 Juni 2017) hal ini dialami olah anggota Gita Rarya dalam progresnya sikap:

1. Tanggung jawab, jika sudah sanggup untuk tugas atau pentas harus dilaksanakan sebaik mungkin, bahkan sebagian besar pernah berlatih sendiri atau bersama teman di luar jadwal latihan.

2. Disiplin, datang latihan tepat waktu, jika berhalangan hadir memberi tahu

3. Kebersamaan, suka duka dalam bertugas dan kehadiran atau ketidakhadiran anggota dirasakan bersama

4. Kerja sama, jika ada anggota yang tidak dapat hadir pada waktu tugas, akan digantikan anggota lain, sehingga memacu anggota untuk belajar menabuh instrumen lain atau yang bukan instrumen yang biasa ditabuh.

5. Komunikasi, antaranggota Gita Rarya lebih dekat karena pada waktu latihan dan tugas banyak melakukan komunikasi dalam memainkan gamelan dan pergaulan.

Ditambahkan oleh Atik (Wawancara tanggal 9 Juli 2017):

6. Kekeluargaan, sikap ini terbukti dengan urusan sarana dan prasarana latihan dan pentas seperti dana penyelenggaraan, kostum pentas atau lomba ditanggung oleh F.X. Wiyono dan orang tua anggota Gita Rarya.

Aspek ketiga merupakan aspek psikomotor yaitu nglakoni bagaimana seseorang melakukan aktifitas, kegiatan atau praktik untuk membuktikan lebih memperdalam teori yang telah dipelajari, dalam hal ini adalah kemampuan memainkan gamelan. Umur Gita Rarya sudah 10 tahun lebih. Gita Rarya nglakoni dengan baik dalam menabuh gamelan untuk tugas rutin mengiringi kor di dalam dan luar gereja, lomba, dan sebagainya.

Dari segi pelatih, menurut Ki Hadjar Dewantara (2013: 28) ada 6 cara mendidik:

1. Memberi contoh (yang sesuai diterapkan anak usia 1-7 tahun), hal ini dilakukan F.X. Wiyono dengan memberi contoh menabuh setiap instrumen dan mendatangkan anak-anak lain yang lebih dahulu kenal dengan karawitan untuk mendampingi saat tugas

2. Pembiasaan (yang sesuai diterapkan anak usia 1-7 tahun), membiasakan diri membaca teks dan latihan rutin serta latihan nersama kelompok kor adalah bentuk pembiasaan.

3. Pengajaran (yang sesuai diterapkan anak usia 7-14 tahun), diterapkan dengan teori pengetahuan menabuh yang baik dengan aturan pakem dan varianny, misalnya imbal saron dan bonang

4. Perintah, Paksaan, dan Hukuman (yang sesuai diterapkan anak usia 7-14 tahun), jarang dilaksanakan pada anggota Gita Rarya. Meskipun demikian, kata Daisy pada kedua anaknya yang ikut Gita Rarya (Wawancara, 23 Juni 2017) anak harus sedikit dipaksa pada saat sedang malas dengan mengingatkan bahwa sifat malas harus disingkirkan kalau ingin maju dalam menabuh. Jika sedah selesai latihan boleh tidur atau bersantai lagi. Namun demikian, hukuman tidak terjadi pada Gita Rarya 
5. Laku, (yang sesuai diterapkan anak usia 14-21tahun), Gita Rarya melaksanakan laku sebagai tugas yang harus dilaksanakan dengan penuh tanggung jawab. Terbukti dengan dilaksanakan tugas rutin mengiringi kor di gereja selama lebih dari 10 tahun.

6. Pengalaman Lahir dan batin (yang sesuai diterapkan anak usia 14-21 tahun), Pengalaman 10 tahun menjadi anggota Gita Rarya, menjadikan anggotanya mempunyai pengalaman yang cukup luas. Pengalaman lahir juga disalurkan beberapa anggotanya dengan berbagi keterampilan dengan membimbing saudara dan teman-temannya yang ingin belajar menabuh gamelan, seperti yang dilakukan Greta dengan mendampingi anak-anak di Wilayah Gunung Sempu Wawancara dengan Daisy, 23 Juni 2017). Pengalaman batin tentunya juga tidak kalah indah dengan meningkatnya iman yang diwujudkan dalam mengambil bagian dari rangkaian liturgi Katolik,

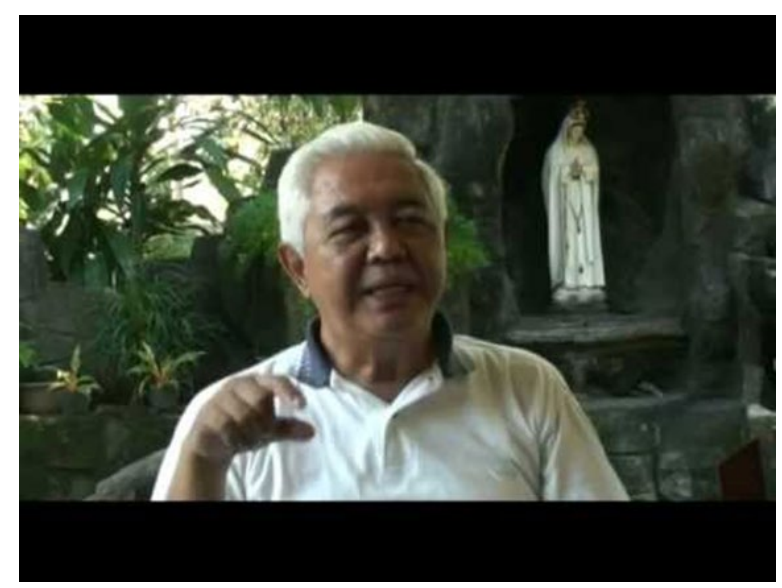

\section{Penutup}

Simpulan hasil penelitian ini kelompok karawitan Remaja Gita Rarya selama 10 tahun lebih secara konsisten mengambil bagian dalam pelaksanaan liturgi Katolik di GHKTY Pugeran dengan menjadi pengrawit gending Gereja untuk mengiringi kelompok kor, terutama Kor Lingkungan Mangkuyudan. Sebagai kelompok pengrawit pemula kelompok karawitan Gita Rarya mengalami progres dalam penguasaan cara menabuh gending-gending gereja yakni teknik menabuh terutama tabuhan imbal.

Karawitan liturgi yang diterapkan pada kelompok karawitan remaja Gita Rarya sama dengan yang diterapkan kelompok lain yang bertugas sebagai pengiring kor bahkan beberapa gending digarap dengan lebih rancak untuk menambah semangat anggotanya. Kelompok karawitan remaja Gita Rarya mempunyai rasa musikalitas cukup tinggi dengan bukti cepat menangkap pelajaran menabuh dan dalam waktu relatif singkat sudah dapat bertugas mengiringi kor di Gereja.

Di samping itu, dari aspek nonmusikal terlihat dampak psikologi dan sosial akibat pergaulan selama ini yakni tingginya rasa percaya diri karena mengenal karawitan sebagai salah satu wujud kebudayaan, keinginan untuk melestarikan karawitan sampai waktu yang tidak terhingga dan rasa kebersamaan dan kekeluargaan antaranggota Gitararya. Hal paling mendasar bahwa kelompok karawitan remaja Gita Rarya eksis sebagai pengrawit di GHKTY Pugeran karena belajar dan melakukan semua tugasnya dengan rasa senang.

\section{Referensi}

Majelis Luhur Persatuan Tamansiswa. 2013. Ki Hadjar Dewantara, Pemikiran, Konsepsi, Keteladanan, Sikap Merdeka I (Pendidikan, UST Press, Yogyakarta.

Martopangrawit. 1975. "Pengetahuan

Karawitan I". Surakarta: ASKI Surakarta.

Noeng Muhadjir. 2000, Metodologi Penelitian Kualitatif, Rake Sarasin, Yogyakarta.

Prier, Karl Edmund.2009.Kamus Musik. Yogyakarta: Rejeki. 
Soedarsono, R.M. 2001, Metodologi Penelitian Seni Pertunjukan dan Seni Rupa. MSPI, Bandung.

Subuh. 2006. Gamelan Jawa Inkulturasi musik Gereja: Studi Kasus GendingGending Karya C. Hardjasoebroto, STSI Press, Surakarta.

Sumandiyo Hadi, Y. 2000, Seni Dalam Ritual Agama, Yayasan Untuk Indonesia, Yogyakarta.

Sumardi. 2012, "Konsep Pendidikan Ajaran Ki Hajar Dewantara", Makalah Mata Kuliah Filsafat Ilmu, Program Pascasarjana, Universitas Sarjanawiyata Tamansiswa, Yogyakarta, Yogyakarta.

Sukatmi Susantina. 2001, Inkulturasi Gamelan Jawa, Studi Kasus di Gereja Katolik Yogyakarta, Med Print Offset, Yogyakarta.

Tim Redaksi. 2004. "Menuju Paroki Mandiri dan Dewasa", Buku Kenangan 70 Tahun Gereja Hati Kudus Tuhan Yesus, Yogyakarta.

Tim Redaksi. 2014, “Peduli, Berbagi, Gembira", Buku Kenangan Delapan Puluh Tahun Gereja Hati Kudus Tuhan Yesus, Yogyakarta

Tridiatno, Agus. 2010. "Peranan Kor dalam Liturgi", makalah Rekoleksi Kelompok Kor Wilayah Kraton, Godean, Yogyakarta. 